\title{
The Effect of Crocin on Endocrine Functions of the Testes before and after Testicular Damage in Rats
}

\author{
NESREN M.M. ABO EDRA, M.Sc.; ABEER A. AHMED, M.D.; MERVAT H. EL-SAKA, M.D. and \\ SAHAR A. EL-SAWY, M.D.
}

The Department of Physiology, Faculty of Medicine, Tanta University

\begin{abstract}
Aim of the Work : The aim of this work is to study the effect of crocin on endocrine functions of testes before and after testicular damage in rats.

Methods: The present work will be carried on 40 male albino rats. The rats will be divided into four groups, (10 rats for each). Control group (group I): Rats received $1 \mathrm{ml}$ normal saline intraperitoneally. Cadmium-treated group (group II): Rats received intraperitoneal injection of a single dose of 1 $\mathrm{mg} / \mathrm{kg}$ cadmium chloride dissolved in saline. Crocin-pretreated group (group III): Rats received crocin in a dose of $50 \mathrm{mg} / \mathrm{kg}$ intra-peritoneally once daily for 4 weeks, then they received cadmium chloride as in group II. Crocin-treated group (group IV): Rats received cadmium chloride as in group II, then they treated with crocin as in group III. At the end of the experiment, the animals were anesthetized, then the animals were sacrificed by cervical decapitation. The collected blood samples were collected.
\end{abstract}

Results: At the end of the experimental period, the results of the present work revealed that in Cd-treated group, there was significant decrease of serum levels of testosterone, FSH and LH. On the other hand, there was significant increase of testicular caspase- 3 and testicular MDA with concomitant significant decrease of testicular GSH level compared to normal control group. In both the crocin-pretreated group and crocin-treated groups, there was significant increase of serum levels of testosterone, FSH and $\mathrm{LH}$, significant decrease of testicular MDA levels associated with significant increase of testicular GSH levels as compared to cadmium-treated group. Testicular caspase-3 significanlty decreased in the crocintreated group, but insignificanlty changed in crocin-pretreated as compared to cadmium-treated group. Also, all studied parameters significantly improved in crocin-treated group as compared to the crocin-pretreated group.

Conclusion: We conclude that crocin can improve testicular toxicity induced by cadmium via its anti-apoptotic and antioxidant effects. Moreover, our results showed that the therapeutic effect of crocin is more effective than its protective effect on testicular toxicity induced by $\mathrm{Cd}$.

Correspondence to: Dr. Nesren M.M. Abo Edra, E-Mail: nesrenmohamed8@yahoo.com.
Key Words: Crocin-Cadmium-Testosterone-Caspase-3 $-M D A$.

\section{Introduction}

CROCIN is a carotenoid obtained from Crcus stivaus L. (Saffron) and is responsible for the red color of saffron [1]

Saffron has been used as a flavoring agent [2] In traditional medicine, saffron has been used to treat infertility and impotence, but the mechanism is still un clear [3] . It contains crocin, crocetin, picrocrocin and safranal [4]

Hosseinzadeh et al., [я demonstrated that crocin has various activities as antioxidant, antitumor, radical scavenging and genoprotective.

There are many environmental toxicants have the potential to impair human fertility [6]. The testis is sensitive to a variety of stressors, such as inflammation, radiation, hyperthermia and exposure to agents that induce testicular damage [7]. These agents may include phthalates, bisphenol A, polychlorinated biphenyls, pesticides, polybrominated diphenyl ethers and others (e.g., cadmium chloride) [8]

The impacts of exposure to certain toxicants may not be fully realized. Campion et al., [9] suggested that these environmental toxicants produce their effects by perturbation the reproductive system either by direct or indirect interaction with vital cellular components and disruption of hormonal and paracrine interactions essential for reproduction.

The aim of this work is to study the effect of crocin on endocrine functions of testes before and after testicular damage in rats. 


\section{Material and Methods}

\section{Animals:}

The present work was carried out on 40 male adult albino rats oflocal strain weighing (180-200 $\mathrm{gm})$. The rats were housed in isolatedanimal cages, five in each cage, in a standard Animal Laboratory Room in Faculty of Medicine, Tanta University and had free access towater and food ad libtium all over the period of the work, and were kept atroom temperature. All procedures were done according to the ethicalcommittee of Tanta University. The work was done from April 2016 to Nov. 2017.

\section{Chemicals:}

- Crocin preparation:Crocin was obtained from Sigma-Aldrish Co as a powder and dissolved by addition of normal saline.

- Cadmium Choloride (Cd) preparation:Cd was obtained from Sigma Aldrish as a powder dissolved by addition of normal saline.

\section{Study design:}

Rats were divided into four main groups: Each consisting of 10 animals.

1- Control group (group I): Rats received $1 \mathrm{ml}$ normal saline intraperitoneally for 4 weeks.

2- Cadmium-treated group (group II): Rats received intraperitoneal injection of a single dose of $1 \mathrm{mg} / \mathrm{kg}$ cadmium chloride dissolved in saline [10].

3- Crocin -pretreated group (group III):Rats pretreated with crocin in a dose of $50 \mathrm{mg} / \mathrm{kg}$ intraperitoneally once daily for 4 weeks [11], then they received cadmium chloride as in group II [10].

4- Crocin-treated group (group IV): Rats received cadmium chloride as in group II, then they were treated with crocin as in group III for 4 weeks [11].

\section{Sample collection and analysis:}

At the end of the experimental period, all rats were anaesthetized by intraperitoneal injection of pentobarbital $(50 \mathrm{mg} / \mathrm{kg})$ [12] and blood samples were obtained by decapitation of all animals then serum was separated by centrifugation at $3000 \mathrm{rpm}$ for 10 minutes and transferred into clean storage tubes.

Serum samples were used to measure free testosterone level according to the method of Morley et al., [13], FSH level according to the method described by Gay et al., [14], and LH according to the method of Haavisto et al., [15].

Part of testis was homogenized in ice-cold sodium potassium phosphate buffer ( $\mathrm{pH}$ 7.4), centrifuged at $3000 \mathrm{rpm}$ at for $10 \mathrm{~min}$ and stored at $-80^{\circ} \mathrm{C}$ for analysis of caspase- 3 activity according to the method of Slee et al., [16], Malondialdehyde (MDA) according to the method of Ohkawa et al., [17] and Gutathione (GSH) by the method of Moron et al., [18]

\section{Statistical analysis:}

The data were shown as the mean \pm standard deviation. Data from the study were analyzed using by one-way Analysis of Variance (ANOVA) followed by Tukey' s test to assess the significance. The $p<0.05$ were considered as statistically significant. Using SPSS for windows (Version 23.0).

\section{Results}

Effect of the crocin on serum testosterone, FSH \& LH levels:

As shown in Fig. (1), there was significant decrease of serum levels of testosterone, FSH and LH in Cd-treated group as compared to the normal control group. While, Crocin pretreatment, for 4 weeks before $\mathrm{Cd}$ toxicity, significantly increased serum levels of testosterone, FSH and LH as compared to Cd-treated group. But, these levels were still significantly low as compared to the normal control group.

As regard, crocin-treated group, also, there was significant increase in serum levels of testosterone, FSH and LH as compared to Cd-treated group. These parameters returned to the normal level as compared to the normal control group.

\section{Effect of the crocin on testicular caspase-3} activity:

As presented in Fig. (2), there was significant increase of testicular caspase- 3 activity levels in $\mathrm{Cd}$ treated group as compared to the normal control group. While, as regard, crocin-pretreated group, there was insignificant change of testicular caspase3 as compared to $\mathrm{Cd}$-treated group.

But, in crocin-treated group, the results showed that there was significant decrease in testicular caspase-3 level as compared to Cd-treated group. The level of caspase- 3 activity returned to the normal level as compared to the normal control group. 

GSH:

Effect of the crocin on testicular MDA and

Fig. (3) showed that MDA levels significantly dcereased in testicular tissue with concomitant increase of testicular GSH levels as compared to the normal control group. As regard, crocin-treated group, MDA levels significantly decreased in testicular tissue with concomitant increase of testicular $\mathrm{GSH}$ levels as compared to Cd-treated group.
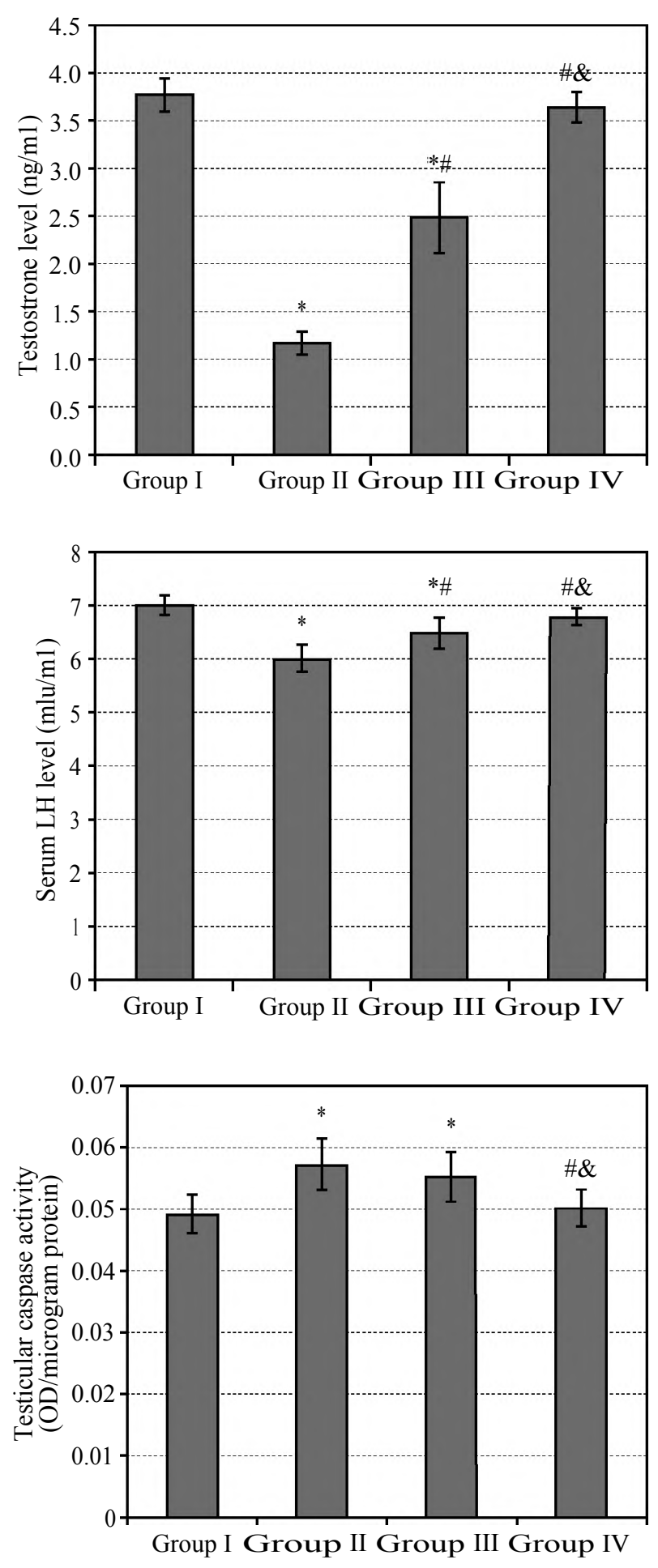

However, these levels were still significantly changed as compared to the normal control group.

Also, in crocin-treated group, MDA levels significantly decreased in testicular tissue with concomitant increase of testicular GSH levels as compared to Cd-treated group. These parameters returned to the normal level as compared to the normal control group.

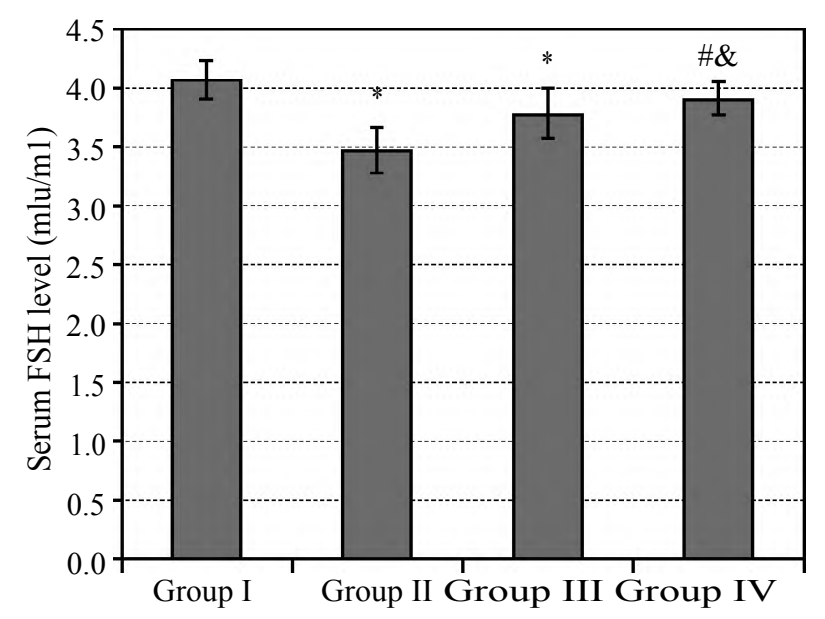

Fig. (1): Effect of crocin onserum testosterone, FSH \& LH levels.

Data are given as mean $\pm \mathrm{SD}$.

$*: p<0.05$ vs. normal control group.

\#: $p<0.05$ vs. Cd-treated group.

$\&: p<0.05$ vs. Crocin-pretreated group.

Fig. (2): Effect of the crocin on testicular caspase-3 activity.

\footnotetext{
Data are given as mean $\pm \mathrm{SD}$.

$*: p<0.05$ vs. normal control group.

$\#: p<0.05$ vs. Cd-treated group.

$\&: p<0.05$ vs. Crocin-pretreated group.
} 

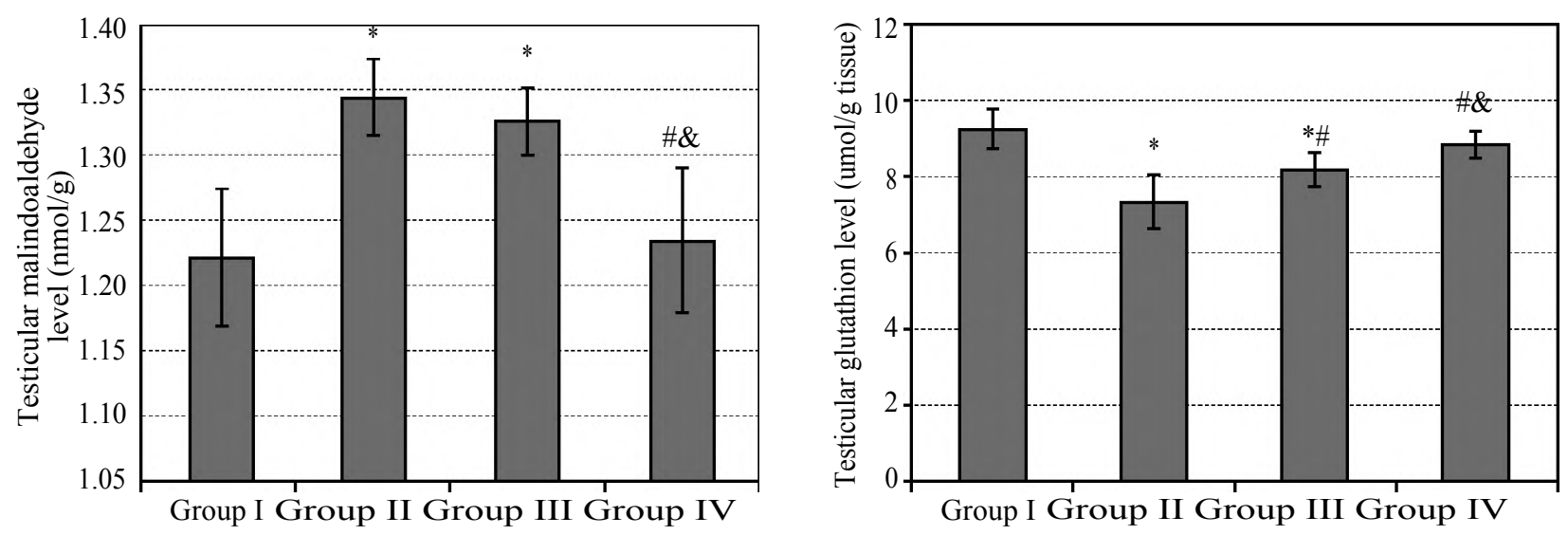

Fig. (3): Effect of the crocin on testicular MDA and GSH.

Data are given as mean $\pm \mathrm{SD}$.

$*: p<0.05$ vs. normal control group.

$\#: p<0.05$ vs. Cd-treated group.

$\&: p<0.05$ vs. Crocin-pretreated group.

\section{Discussion}

The results of the present work revealed that in Cd.-treated group, there was significant impairment of endocrinal function of testes. Also, there was evidence of apoptosis of the testicular tissue manifested by significant increase of testicular caspase-3 levels. In addition, there was evidence of oxidative stress in testicular tissue. The result of the present work showed the efficacy of crocin in preventing and/or treating the toxic effects of $\mathrm{Cd}$ in the rat testes.

In the present work, the results showed that the serum level of testosterone significantly decreased in Cd-treated group as compared to the normal control group.

The mechanism by which Cd mediate the decrease in the serum testosterone level observed after $\mathrm{Cd}$ administration is still not well known.

One proposed mechanism for the decrease of serum testosterone level after $\mathrm{Cd}$ administration can be explained by that $\mathrm{Cd}$ exposure at the testicular level causes significantly decreased activity of testicular steroidogenic enzymes 3-B-hydroxysteroid dehydrogenase and 17-hydroxysteroid dehydrogenase which are the key enzymes for testosterone biosynthesis [19]

Another possible mechanism is that $\mathrm{Cd}$ exposure increased intracellular concentration of Reactive Oxygen Species (ROS) with increased peroxidation, protein carbonylation and DNA fragmentation [20]

A third mechanism, Cd can also affect testosterone synthesis by down-regulating LH receptors mRNA expression [10].
Also, it was suggested that Cd decreases androgen biosynthesis, possibly by altering progesterone synthesis and metabolism through direct interaction of $\mathrm{Cd}$ with DNA and competitive inhibition of essential enzymes [21]. Testicular lesion from $\mathrm{Cd}$ exposure is primarily vascular and the vascular damage determines the degree of lesion in the germ cells and leydig cells. This lesion can generate leydig cells degeneration and atrophy [22]

Moreover, the decreased testosterone level may be explained considering the results described by [23] from vitro studies that showed a reduction in human chroinic gonadotropin and dibutyl cyclic adenosine monophosphate stimulated testosterone production in rats treated with $\mathrm{Cd}$.

In the present work, the results showed that the serum levels of both FSH and LH were significantly decreased in Cd-treated group as compared to the normal control group.

The mechanism of the decreased serum levels of FSH and LH after Cd toxicity cannot be elucidated, but it can be explained by that Cd is considered as an endocrine disruptor and the hypothalamopituitary-gonadal axis is a target for $\mathrm{Cd}$ [24] .

The pituitary gland is a very sensitive target for Cd [25]. It was suggested that oxidative stress and lipid peroxidation may be a mechanism of Cdtoxic activity on pituitary gland so causes decrease of FSH and LH [26].

In the same way, Lafuente [27] demonstrated that $\mathrm{Cd}$ administration lowered the membrane fluidity of the pituitary gland, which may affect membrane function and alteration of receptor bind- 
ing and secretory mechanisms of pituitary hormones.

Also, Ma et al., [28] observed that treatment of $\mathrm{Cd}$ exerted disruption in the hypothalamic-pituitaryaxis function, with subsequent decrease of both FSH and LH levels.

As observed in the results of the present work, the serum testosterone levels significantly increased in both group III (pretreated-crocin group) and group IV (treated-crocin group) as compared to the Cd-treated group which suggested that crocin administration improves the endocrine testicular function.

The mechanism by which the serum testosterone level increased via crocin administration is still unclear. But, it can be explained by that crocin increases the leydig cells activity and steriodogenesis process of leydig cells with subsequent increase of testosterone level [29]

Another mechanism that can explain the increase of testosterone serum levels by crocin administration is that crocin through enhancing the defense antioxidant system and reduction of oxidative stress and hence decreasing the oxidative damages on cellular processes and steroidogenesis in leydig cells [30].

It is clear from the results of the present work, that crocin administration before and after $\mathrm{Cd}$ administration not only significantly increased serum testosterone level but also, there were concomitant significant increase of serum FSH and LH levels.

The mechanism by which crocin significantly increased serum levels of FSH and LH is still not well established. But, Kreft and Zorec [31] demonstrated that crocin cause significant growth of anterior pituitary secretion cells number with subsequent increase of FSH and LH secretions.

Also, Sajjadi and Bathaie, [32] observed that studying colored tissue of the anterior pituitary cleared distinct accretion in basophil cells which responsible for $\mathrm{LH}$ and FSH production.

Also, Asadi et al., [33] explained the FSH and LH increased levels with the increased testosterone level, as that crocin may reduce the hypophysealhypothalamic sensitivity to testosterone feedback control on gonadotropins secretion.

One of the possible explanations of the increased levels of FSH, LH and testosterone with crocin administration may be due to presence of compounds in crocin which affect the hypothalamus-pituitary axis and has thus increased concentration of these hormones [3]

The researches done by Krsmavic et al., [34] also showed that crocin is capable of releasing $\mathrm{LH}$ hormone by affecting hypothalamus axis and increasing the secretion rate of $\mathrm{GnRH}$ hormone.

Also, Kumar and Sharma [35], proposed that GnRH cause proliferation of sex cells by increasing the leydig cells activities in adult rats.

In another explanation, Khazdair et al., [36] showed that crocin increase norepinephrine, and this hormone can increase the release of nitric oxide. Norepinephrine increase LH secretion with activation of nitric oxide. Nitric oxide affects hypothalamus axis and release GnRH. The latter increases secretion of other hormones such as $\mathrm{LH}$ and FSH of pituitary gland. LH hormone affects leydig cells with subsequent release testosterone hormone.

The result of the present work showed that the testicular caspase activity significantly increased after $\mathrm{Cd}$ administration as compared to the control normal group.

The apoptosis process induced by $\mathrm{Cd}$ is mitochondrial dependent in both the in vitro and in vivo condition [37]

The mechanism conferring increased caspase3 after $\mathrm{Cd}$ administration is not understood, but it has been suggested to result from oxidative stress induced by $\mathrm{Cd}$ as proved in the results of the present work.

In order to gain insight into other possible mechanisms that that mediate the beneficial effects of crocin on Cd-induced testicular damage, measurement of the caspase-3 activity in testicular tissue was undertaken.

The results of the present work showed that the activity of caspase-3 in testicular tissues significantly increased in crocin-treated group for 4 weeks after Cd treatment, but insignificantly changed in crocin-pre-treated group as compared to $\mathrm{Cd}$ - treated group.

The mechanism by which the crosin significantly inhibits the caspase- 3 activity in testicular tissue is not completely understood, but it can be suggested that to result from promotion of antioxidant status and reduction of lipid peroxidation as proved latter in the results in the present work. 
The results of the present work demonstrated that intra-peritoneal injection of $\mathrm{Cd}$ in a single dose of $1 \mathrm{mg} / \mathrm{kg}$, significantly increased MDA levels in testicular tissue as compared to the normal control group.

MDA, an end product of polyunsaturated fatty acids, is a reliable and commonly used biomarker for assessing lipid peroxidation. Lipid peroxidation is a well-established mechanism of cellular injury and is used as an indicator of oxidative stress in cells and tissues.

The depleted GSH level was observed in Cdtreated group in the results of the present work.

The possible mechanism in Cd-induced GSH depletion may be due to rampant lipid peroxidation process that affect the activity of non-enzymatic thiol antioxidant GSH which get utilized to minify the peroxidation of lipids [38]

The results of the present work showed that in crocin-pretreated and treated groups, there was a significant decrease of testicular MDA level with concomitant increase of GSH level in testicular tissue as compared to the Cd-treated group, with observation, that these levels return to the normal control values in crocin-treated group.

These results are consistent with a large of studies highlighting the antioxidant properties of crocin in different tissues. Accordingly, Rajaei et al., [39] proved that crocin at doses of 30 and $60 \mathrm{mg} / \mathrm{kg}$, appear to exert antioxidant activity by decreasing lipid peroxidation in liver and kidney tissues.

Similary, Hossein Zadeh et al., [5] reported that crocin has antioxidant effects.

Also, Vakili et al., [40] indicated that crocin has protective effects against ischemic/reperfusion injury and cerebral edema in a rat model of stroke and significantly reduced MDA content in the ischemic cortex.

Moreover, Razavi and Hosseinzadeh, [41] found that crocin has the ability to reduce lipid peroxidation and improved GSH in liver of rats treated with cisplatin.

\section{Conclusion:}

From these results, we concluded that crocin has protective and therapeutic effect testicular damage-induced by cadmium via improving the endocrine tesicular function and via its antiapoptotic and and antioxidant effect. Also, our results showed that the therapeutic effect of crocin is more effective than its protective effect on testicular toxicity induced by $\mathrm{Cd}$. However, further studies are required to define its exact mechanism of actions.

\section{References}

1- MOHAMADPOUR A.H., AYATI Z. PARIZADEH M.R., RAJBAI O. and HOSSEINZADEH H.: Safety evaluation of crocin (a constituent of saffron) tablets in healthy volunteers. Iran J. Basic. Med. Sci., 16 (1): 39-46, 2013.

2- HALATAEI B.A., KHOSRAVI M., ARBABIAN S., SAHRAEI H., GOLMANESH L., ZARDOOZ H., JALILI C. and GHOSHOONI H.: Saffron (crocus sativus) aqueous extract and its constituent crocin reduces stressinduced anorexia in Mice. Phytother. Res. J., 25 (12): 1833-8, 2011.

3- SALAHSHOOR M.R., KHAZAEI M., JALILI C. and KEIVAN M.: Crocin improves damage induced by nicotine on a number of reproductive parameters in male mice. Int. J. Fertil. Steril., 10 (1): 71-8, 2016.

4- MELNYK J.P., WANG S. and MARCONE M.F.: Chemical and biological properties of the world's most expensive spice: Saffron. Food Res. Int., 43 (8): 1981-9, 2010.

5- HOSSEIN ZADEH H., SHAMSAIE F. and MEHRI S. Antioxidant activity of aqueous and ethanolic extracts of crocus sativus L.stigma and its bioactive constituent, crocin and safranal. Pharmacog. Mag., 5 (20): 419-24, 2009.

6- FOSTER W.G.: Environmental toxicants and human fertility. Minerva Ginecol., 55 (5): 451-7, 2003.

7- KUMAR S., KESARI K.K. and BEHARI J.: The therapeutic effect of a pulsed electromagnetic field on the reproductive patterns of male Wistar rats exposed to a 2.45-GHz microwave field.Clinics (Sao Paulo), 66 (7): 1237-45, 2011.

8- CHENG C.Y., WONG E.W., LIE P.P., LI M.W., SU L., SIU E.R., et al.: Environmental toxicants and male reproductive function. Spermatogenesis, 1 (1): 2-13, 2011.

9- CAMPION S., CATLIN N., HEGER N., MCDONNELL E.V., PACHECO S.E., SAFFARINI C., et al.: Male reprotoxicity and endocrine disruption. EXS, 101: 3 15-60, 2012.

10- ELEAWA S.M., ALKHATEEB M.A., ALHASHEM F.H., BIN-JALIAH I., SAKR H.F., ELREFAEY H.M., et al.: Resveratrol reverses cadmium chloride-induced testicular damage and subfertility by downregulating p53 and Bax and upregulating gonadotropins and $\mathrm{Bcl}-2$ gene expression. J. Reprod. Dev., 60 (2): 115-27, 2014.

11- LARI P., ABNOUS K., IMENSHAHIDI M., RASHEDINIA M., RAZAVI M. and HOSSEINZADEH H.: Evaluation of diazinon-induced hepatotoxicity and protective effects of crocin. Toxicol. Ind. Health, 31 (4): 367-76, 2015.

12- ALLEN-WORTHINGTON K.H., BRICE A.K., MARX J.O. and HANKENSON F.C.: Intraperitoneal Injection of Ethanol for the Euthanasia of Laboratory Mice (Mus musculus) and Rats (Rattus norvegicus). J. Am. Assoc. Lab. Anim. Sci., 54 (6): 769-78, 2015. 
13- MORLEY J.E., PATRICK P. andPERRY H.M. 3RD Evaluation of assays available to measure free testosterone. Metabolismm 51 (5): 554-9, 2002.

14- GAY V.L., MIDGLEY A.R. JR. and NISWENDER G.D.: Patterns of gonadotropin secretion associated with ovulation. Fed. Proc.m 29: 1880-7, 1970.

15- HAAVISTO A.M., PETTERSSON K., BERGENDAHL M., PERHEENTUPA A., ROSER J.F. andHUHTANIEMI I.: A supersensitive immunofluorometric assay for rat luteinizing hormone. Endocrinologym 132 (4): 1687-91, 1993.

16- SLEE E.A., HARTE M.T., KLUCK R.M., WOLF B.B., CASIANO C.A., NEWMEYER D.D., et al.: Ordering the cytochrome c-initiated caspase cascade: Hierarchical activation of caspases- $2,-3,-6,-7,-8$, and -10 in a caspase9-dependent manner. J. Cell. Biol., 144 (2): 281-92, 1999.

17- OHKAWA H., OHISHI N., and YAGI K.: Assay for lipid peroxides in animal tissues by thiobarbituric acid reaction. Anal. Biochem., 95 (2): 351-8, 1979.

18- MORON M.S., DEPIERRE J.W. and MANNERVIK B.: Levels of glutathione, glutathione reductase and glutathione S-transferase activities in rat lung and liver. Biochimica et Biophysica Acta., 582: 67-78, 1979.

19- RASMUSSEN M.K., EKSTRAND B. and ZAMARATSKAIA G.: Regulation of 3 (3-Hydroxysteroid Dehydrogenase/ $\Delta-\Delta$ Isomerase: A Review. Int. J. Mol. Sci., 14 (9): 17926-42, 2013.

20- MATEEN S., MOIN S., KHAN A.Q., ZAFAR A., and FATIMA N.: Increased reactive oxygen species formation and oxidative stress in rheumatoid arthritis. PLoS One, 11 (4): e0152925, 2016.

21- CADAGAN D., KHAN R. and AMER S.: Female adipocyte androgen synthesis and the effects of insulin. Mol. Genet. Metab. Rep., 1: 254-63, 2014.

22- ADAMKOVICOVA M., TOMAN R., CABAJ M., MASSANYI P., MARTINIAKOVA M., OMELKA R., et al.: Effects of subchronic exposure to cadmium and diazinon on testis and epididymis in rats. The Scientific World Journal Volume, Article ID 632581, 9 pages, 2014.

23- MEEKER J.D., ROSSANO M.G., PROTAS B., PADMANAHBAN V., DIAMOND M.P., PUSCHECK E., et al.: Environmental exposure to metals and male reproductive hormones: Circulating testosterone is inversely associated with blood molybdenum. Fertil Steril, 93 (1): 13040, 2010.

24- SIU E.R., MRUK D.D., PORTO C.S. and CHENG C.Y. Cadmium-induced testicular injury. Toxicol. Appl. Pharmacol., 238 (3): 240-9, 2009.

25- RONCHETTI S.A., MILER E.A., DUVILANSKI B.H., and CABILLA J.P.: Cadmium Mimics Estrogen-Driven Cell Proliferation and Prolactin Secretion from Anterior Pituitary Cells. PLoS One, 8 (11): e81101, 2013.

26- POLLACK A.Z., SCHISTERMAN E.F., GOLDMAN L.R., MUMFORD S.L., ALBERT P.S., JONES R.L., et al.: Cadmium, lead, and mercury in relation to reproductive hormones and anovulation in premenopausal women. Environ Health Perspect., 119 (8): 1156-61, 2011.
27- LAFUENTE A.: The hypothalamic-pituitary-gonadal axis is target of cadmium toxicity. An update of recent studies and potential therapeutic approaches. Food Chem. Toxicol., 59: 395-404, 2013.

28- MA S.H., ZHANG L.L. and JIANG Q.Q.: Protective effect of bio avonoid morin on Cadmium induced oxidative neuropathy. Biomedical Research, 105: 138-47, 2016.

29- MANNA P.R., JO Y. and STOCCO D.M.: Regulation of Leydig cell steroidogenesis by extracellular signalregulated kinase 1/2: Role of protein kinase $A$ and protein kinase C signaling. J. Endocrinol., 193 (1): 53-63, 2007.

30- KHAYATNOURI M., SAFAVI S.E., SAFARMASHAEI S., BABAZADEH D. and OURARDABILI B.: The effect of saffron orally administration on spermatogenesis index in rat. Advances in Environmental Biology, 5 (7): 1514$21,2011$.

31- KREFT M. and ZOREC R.: Anterior pituitary cells excited by GABA. J. Physiol., 586 (Pt 13): 3023-4, 2008.

32- SAJJADI M. and BATHAIE Z.: Comparative study on the preventive effect of saffron carotenoids, crocin and crocetin, in nmu-induced breast cancer in rats. Cell J., 19 (1): 94-101, 2017.

33- ASADI M.H., ZAFARI F., SARVEAZAD A., ABBASI M., SAFA M., KORUJI M., et al.: Saffron improves epididymal sperm parameters in rats exposed to cadmium. Nephrourol. Mon., 6 (1): e12125, 2013.

34- KRSMANOVIC L.Z., HU L., LEUNG P.K., FENG H., and CATT K.J.: The hypothalamic GnRH pulse generator: Multiple regulatory mechanisms. Trends Endocrinol. Metab., 20 (8): 402-8, 2009.

35- KUMAR P. and SHARMA A.: Gonadotropin-releasing hormone analogs: Understanding advantages and limitations. J. Hum. Reprod. Sci., 7 (3): 170-4, 2014

36- KHAZDAIR M.R., BOSKABADY M.H., HOSSEINI M., REZAEE R. andTSATSAKIS M.A.: The effects of Crocus sativus (saffron) and its constituents on nervous system: A review. Avicenna J. Phytomed., 5 (5): 376-91, 2015.

37- SINGH P.K. and KUMAR A.: Mitochondria mediates caspase-dependent and independent retinal cell death in Staphylococcus aureus endophthalmitis. Cell Death Discov., 2: 16034, 2016.

38- NAM T.: Lipid peroxidation and its toxicological implications. Toxicol. Res., 27 (1): 1-6, 2011.

39- RAJAEI Z., HADJZADEH M.A., NEMATI H., HOSSEINI M., AHMADI M. and SHAFIEE S.: Antihyperglycemic and antioxidant activity of crocin in streptozotocin-induced diabetic rats. J. Med. Food, 16 (3): 206-10, 2013.

40- VAKILI A., EINALI M.R. and BANDEGI A.R.: Protective effect of crocin against cerebral ischemia in a dosedependent manner in a rat model of ischemic stroke. J. Stroke Cerebrovasc Dis., 23 (1): 106-13, 2014.

41- RAZAVI B.M. and HOSSEINZADEH H.: Saffron as an antidote or a protective agent against natural or chemical toxicities. Daru., 1; 23: 31.9 pages, 2015. 


\section{دراسة تآثير الكورسين على وظائف الخصية الهربية الهمونية

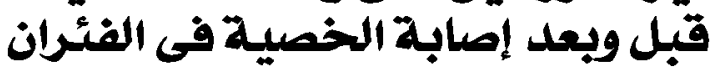

الهدف من البحث: يهدف هذا البحث إلى دراسة تآثير الكروسين على وظائف الغدد الصماء للخصيتين قبل وبعد تلف الخصية المستحدث بالكادميوم فى الفئران.

الطريقة: تم إجراء البحث على • ع فآرا من القئران البيضاء تم تقسيمها إلى آربع مجموعات متساوية فى العدد تحتقى كل مجموعة على ـا فئران.

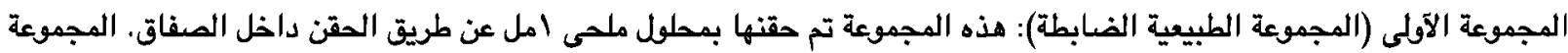

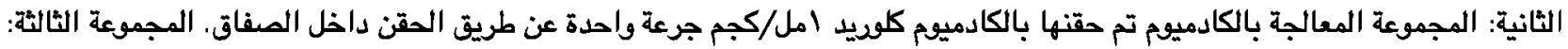

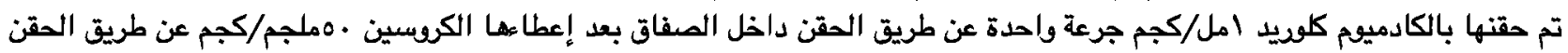

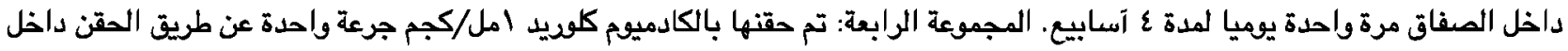

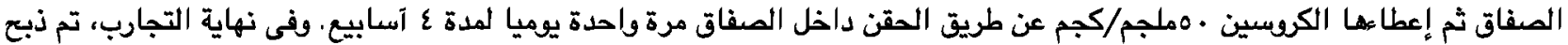

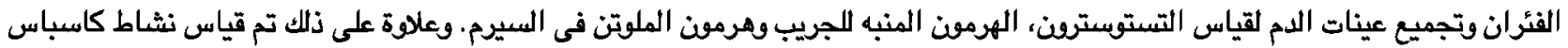

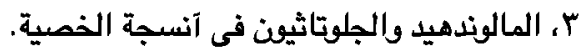

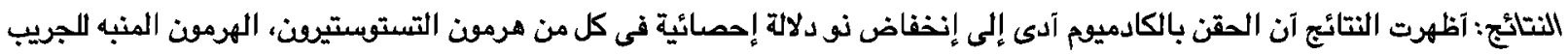

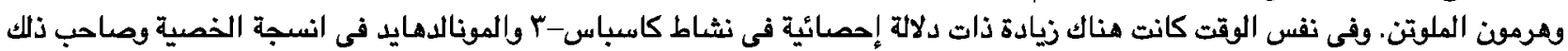

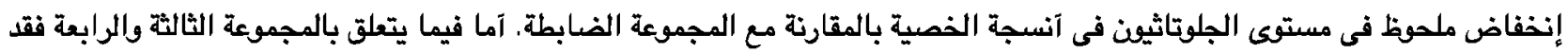

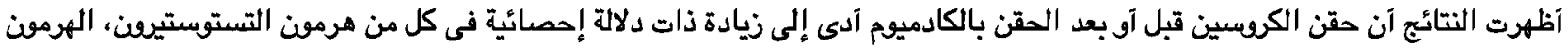

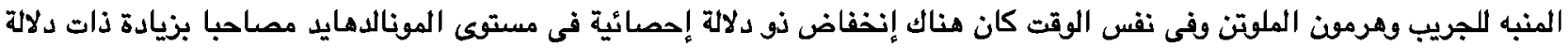

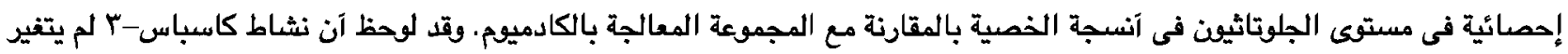

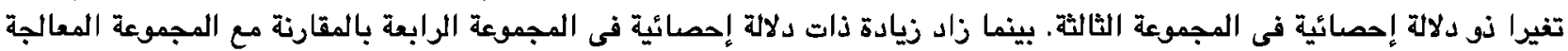
بالكادميوم.

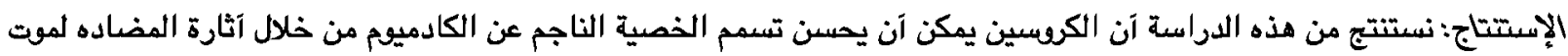

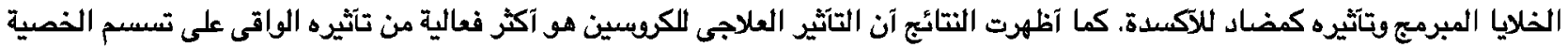
الناجم عن الكادميوم المبرمباتئر 